\title{
HET WISSELINGSPROCES VAN DE GENTSE SCHEPENEN TIJDENS DE 15de EEUW
}

door

\author{
W.P. BLOCKMANS
}

De belangstelling voor de samenstelling van stadsbesturen heeft een lange traditie. Lijsten van leden van de magistraat werden vaak opgetekend in de stadsrekeningen, zoals bv. te Nieuwpoort; of ze werden na verloop van enige jaren gebundeld in een Register van Wetvernieuwingen, zoals te Bragge (bv. 1468-1501) ; dergelijke lijsten werden in vele steden ook in latere eeuwen gecompileerd en gecopieerd. Historici hebben in de loop van de 19de eeuw evenzeer een prioriteit gezien in het afdrukken van magistraatslijsten, zoals dat toen geschiedde voor Oudenaarde en Gent ${ }^{1}$. Hoewel deze lijsten veelal gekenmerkt worden door een geringe nauwkeurigheid en een wisselende opgave van preciseringen die de identificatie moeten ondersteunen - zoals titels, verwantschapsbanden, woonplaats of beroep - vormen zij toch een bruikbaar uitgangspunt voor de studie van de politieke elites. Een voorwaarde is daarbij dat de opgaven uit de magistraatslijsten worden geverifieerd in contemporaine bronnen zoals stadsrekeningen en akten, teneinde vervormingen van namen en andere onjuistheden te corrigeren.

Op die wijze heeft Paul Rogghé verdienstelijke studies verricht naar de samenstelling van de Gentse schepencolleges in de 14 de eeuw ${ }^{2}$. De door hem ingeslagen weg, waarbij hij zich eveneens zeer uitvoerig richtte op de ambtenaren van de stad 3 , wordt sedert enkele jaren op internationaal vlak aangezien als een bijzonder waardevolle en vruchtbare onderzoeksoptiek. Onder de benamingen prosopografie of collectieve biografie wordt thans veel aandacht besteed aan de sociale kenmerken van bepaalde kategorieën mensen, veelal functionarissen. Door systematisch gegevens te verzamelen over het verloop van carrières in een bepaalde instelling of van mensen met een gemeenschappelijke achtergrond, door bovendien na te gaan welke de sociale status was van betrokkenen (inkomens, vermogen, studies, adels- of andere titels, verwantschap, levenswijze etc.) komt men er toe de aloude politieke en instellingsgeschiedenis nieuw leven in te

(1) L. VAN LERBERGHE en J. RONSSE, Lijst van Burgemeesters, Schepenen, oppervoogden en ontvangers, in Audenaerdscbe Mengelingen, 2e deel (Oudenaarde 1846) 174 e.v.; P. C. VAN DER MEERSCH (ed.), Memorieboek der Stad Gbent, 1301-1737, dl. I (Gent 1852), voor de 15de eeuw : 134-379.

(2) Het Gentsche Stadsbestuur van 1302 tot 1345 . Een en ander betreffende het Gentsche stadspatriciaat, in Handelingen wan de Maatschappif voor Gescbiedenis en Oudbeidkunde van Gent, nr. 1 (1944) 1-29; De samenstelling van de Gentse schepenbanken in de 2e helft der 14de eeuw, aldaar, 4 (1950), 22-31.

(3) De Gentse klerken in de XIVe en XVe eeuw. Trouw en verraad, in Appeltjes van het Meetjesland, II (1960), 1-142. 
blazen. Men let nu in het bijzonder op de sociale werkelijkheid, op de mensen die ,het" maakten, en niet zelden in de praktijk heel andere dingen deden dan we zouden opmaken uit de studie van alleen maar normatieve bronnen of registraties van handelingen. Met een vernieuwde aandacht voor de biografie, niet zozeer van prominente persoonlijkheden, maar van allen die tot de gekozen kategorie behoorden, werpt men nieuw licht op de sociale geschiedenis van instellingen ${ }^{4}$.

In het volgende artikel zal ik slechts één aspect aan de orde stellen van de prosopografische benaderingswijze, nl. de wisseling van schepenfuncties.

Van 1359 tot 1540 vond te Gent ieder jaar een algehele wetvernieuwing plaats: geen van de dertien schepenen ,van de Keure" of van de evenzoveel schepenen, ,van Gedele" kon zijn functie tijdens een volgend jaar behouden. Hooguit was wisseling van het ene college naar het andere mogelijk, maar daarna was uittreden gedurende tenminste één jaar de regel 5. De constitutie behield slechts 6 van de 26 zetels voor aan leden van de ,poorterij", de gegoede burgerij die nog gedeeltelijk opklom tot de oude patriciaatsfamilies. De beide prestigieuze posities van voorschepen (de voorzitters van elk college) alsmede de derde en zesde schepenplaatsen bleven hun voorbehouden. Van de overige 20 ambten werden er in elk college vijf toegekend aan de ambachtsgilden van de grote textielindustrie en vijf aan die van de overige ambachten; de twee groepen ambachtslieden genoten per jaar afwisselend elk de voorrang in één college.

Sommige ambachtsgilden konden steeds aanspraak maken op één of twee schepenzetels (de schippers twee, de bakkers, slagers en brouwers elk één, de groep van 6 bouwvakambachten steeds één, die van de 7 lederambachten evenzo steeds één); de kleinere ambachten konden zich niet steeds rechtstreeks laten vertegenwoordigen. De macht van de ambachtslieden werd bovendien nog belichaamd door de twee ,overdekens" die elk voor een ambtsperiode van twee jaar verkozen werden uit respectievelijk de textiel- en de overige ambachten. Zij waren tot de onderdrukking van de Gentse opstand in 1453, en opnieuw van 1477 tot 1492 nauw betrokken bij de aanstelling van de schepenen, samen met andere kiesmannen. Daarnaast oefenden zij ook middels deelname aan allerlei besprekingen en delegaties grote politieke invloed uit. Daarom zijn deze posities mee in beschouwing genomen.

Naast de 26 schepenen en 2 overdekens betrokken we nog de kiesmannen in het onderzoek, die naar gelang van het politiek regime, alleen namens de vorst, dan wel ook namens de stad optraden bij de aanstellings-

(4) Een uitstekend recent overzicht van de problematiek en de literatuur leverde N. BULST, Zum Gegenstand und zur Methode von Prosopographie, in N. BULST en J. Ph. GENET (eds.), Medieval Lives and the Historian. Studes in Medieval Prosopography (Kalamazoo, Michigan 1986) 243-265; in die bundel staan een antal waardevolle voorbeeldstudies; zo ook: F. AUTRAND, Prosopographie et Genèse de l'Etat Moderne (Parijs 1986).

(5) V. FRIS, Les origines de la réforme constitutionnelle de Gand de 1360-1369, in Annales du XXe Congrès de la Fédération d'archéologie et d'bistoire de Belgique (Gent 1907), II, 427-459. 
procedure, zonder zelf in dat jaar een politieke functie te kunnen uitoefenen. Het leek de moeite waard na te gaan in hoeverre dit optreden tijdens volgende jaren beloond werd door wederkerige benoemingen, dan wel volgde op een rol als schepen. Rogghé, die de samenstelling van de 14 de-eeuwse schepencolleges onderzocht, stelde vast dat sedert het weversbewind in 1359, zeker tot 1385 en wellicht langer, de plaatsen niet strikt volgens de 3-5-5 verdeling werden toegewezen. Poorters konden tegelijk lid zijn van een ambacht en uit dien hoofde een ambachtszetel bezetten ${ }^{\circ}$. Het is dus de vraag hoe de wettelijke regeling in de praktijk werd toegepast. Daarbij is ook na te gaan hoe nu eigenlijk de carrière van een Gents schepen verliep, in welke mate er over die jaarlijkse wisselingen heen nog enige continuïteit kon zijn, en welke gemeenschappelijke kenmerken aan te wijzen zijn bij diegenen die de topposities verwierven. Mijn benadering beperkt zich tot de schepenfuncties en tot de kwantificeerbare aspecten daarvan. Verdere sociale identificatie, die uitermate nuttig is, is voor deze studie niet ondernomen. Voor de periode $1400-1506$ verzamelden we de carrièregegevens van 1209 verschillende personen. Dat tijdvak is gekozen omdat het samenvalt met de periode waarvoor de vergaderingen van de Leden en de Staten van Vlaanderen bestudeerd zijn zodat koppeling mogelijk wordt van de lokale loopbaanbeschrijvingen aan die op het niveau van het graafschap ${ }^{7}$. De 15 de eeuw is bovendien getekend door felle conflicten tussen stad en staat ${ }^{8}$ waarom het interessant is de effecten daarvan na te gaan in de samenstelling van het politieke personeel van de grootste stad in de Nederlanden.

In het algemeen leidde het benoemingssysteem tot een hoge mobiliteit van het politiek personeel, die nu in detail wordt bekeken.

Adel was schaars in het Gentse stadsbestuur: amper 28 leden werden gekwalificeerd als mer, heer, jonkbeer of ridder, $2,2 \%$ van het totale politieke personeel. Vier onder hen makkten voor slechts één functie een "apparition", maar 16 bleven meer dan 10 jaren in de roulatie wat er op wijst dat ook het zo sterk door de ambachtslieden bevolkte stadsbestuur juist op de voorzittersplaatsen adellijke figuren naar waarde wist te schatten.

Geschoolde juristen, aangeduid met de meesterstitel, waren vooral te vinden onder de vaste ambtenaren van de stad. Bij de schepenen telden we er slechts 19 ; 5 van hen bekleedden niet meer dan één functie, 11 fungeerden in 4 of meer ambten. Zoals voor de edelen, valt te constateren

(6) ROGGHE toonde an dat de toepassing van de zetelverdeling feitelijk al opklom tot 1359: Samenstelling van de Gentse schepenbanken, 24-29.

(7) Zie de indices op de bronnenuitgave Handelingen van de Leden en van de Staten wan Vlaunderen, in $4^{\circ}$, Kon. Commissie voot Geschiedenis (Brussel 1959 e.v.) bezorgd door W. PREVENIER (1384-1405), A. ZOETE (1405-1419) en W.P. BOCKMANS (1419-1506). De delen betreffende 1419-1467 zijn nu ter perse. De lijst van functionarissen met hun loopbangegevens is gedeponeerd in het Stadsarchief van Gent.

(8) W.P. BOCKMANS, Breuk of continuïteit? De Vlaamse Privilegiën van 1477 in het licht van het staatsvormingsproces, in W.P. BLOCKMANS (red.), 1477, Het Algemene en de gewestelijke privilegiën van Maria van Bonrgondië voor de Nederlanden (Standen en Landen LXXX, Kortrijk-Heule 1985), 122-123. 
dat de meesters een rol speelden die groter was dan in verhouding tot hun kleine aantal verwacht zou kunnen worden.

Beroepsaanduidingen komen slechts in $4 \%$ der gevallen voor in de schepenlijsten, dus niet systematisch en wellicht enkel om identifikatie van homonymen te vergemakkelijken. Wij laten die daarom verder buiten beschouwing.

Tabel 1: Frequentieverdeling van politieke functies

\begin{tabular}{rrrrrrr}
\hline $\begin{array}{l}\text { aantal } \\
\text { functies } \\
\text { per carrière }\end{array}$ & $\begin{array}{l}\text { aantal } \\
\text { personen }\end{array}$ & $\%$ & $\begin{array}{c}\% \text { cumu- } \\
\text { latief }\end{array}$ & $\begin{array}{c}\text { aantal } \\
\text { functies } \\
\text { per kate- } \\
\text { gorie }\end{array}$ & $\%$ & $\begin{array}{c}\% \text { cumu- } \\
\text { latief }\end{array}$ \\
\hline 1 & 439 & 36.3 & 36,3 & 439 & 11,1 & 11,1 \\
2 & 219 & 18,1 & 54,4 & 438 & 11,0 & 22,1 \\
3 & 146 & 12,1 & 66,5 & 438 & 11,0 & 33,1 \\
4 & 115 & 9,5 & 76,0 & 460 & 11,6 & 44,7 \\
5 & 83 & 6,9 & 82,9 & 415 & 10,4 & 55,1 \\
$6-9$ & 152 & 12,6 & 95,5 & 1109 & 27,9 & 83,3 \\
$\geqq 10$ & 55 & 4,5 & 100,0 & 669 & 16,9 & 100,0 \\
\hline & 1209 & 100,0 & & 3968 & 100,0 & \\
\hline
\end{tabular}

De verhouding tussen het aantal te begeven ambten en het aantal fungerende personen is gemiddeld 3,3 tot 1. Gemiddeld oefende een Gents schepen in zijn hele carrière dus niet meer dan 3,3 functies uit, wat op een bijzonder hoog mutatieritme wijst. Aantalllen van ca. 13, 15, 16 en 17 zijn in de literatuur te vinden ${ }^{9}$.

Méér dan een derde van alle Gentse politieke functionarissen oefenden slechts één ambtstermijn uit, twee derden niet meet dan drie. Daar de normale functieduur 1 jaar bedroeg, was er dus een zeer snelle doorstroming. Deze $33 \%$ personen die langer dan 3 jaar in het bestuur bleven, legden daarentegen beslag op $2 / 3$ van alle te begeven ambten.

$Z$ ij die langer dan 5 jaar in functie waren, $17 \%$ van alle personen, vervulden samen $44,9 \%$ van alle ambten. De $10 \%$ meest aktieven (115 personen) bekleedden elk minstens 8 functies, en gemiddeld 10,$2 ; \mathrm{zij}$ legden daarmee beslag op $30 \%$ van alle beschikbare functies. De $90 \%$ anderen oefenden daarentegen gemiddeld 2,5 functies uit.

(9) Voor vergelijkingstnateriaal, zie mijn gelijksoortige studie: Mobiliteit in stadsbesturen 1400-1550, in: D.E.H. DE BOLR en J.W. MARSILJE (red.), De Noordelijke Nederlanden in de Late Middeleeuwen (Utrecht, 1987), 236-260. 
Een snelle doorstroming van $2 / 3$ van het politiek personeel ging dus samen met een vrij sterke concentratie van functies. Toch bleef de voorgeschreven discontinuiteit het onmogelijk maken om hoge aantallen dienstjaren te bereiken. Het hoogst genoteerde aantal van 15 ambten werd slechts door 8 personen gehaald $(=0,66 \%)$.

Tabel 2: Carrièreduur

\begin{tabular}{crrr}
\hline aantal jaren & personen & $\%$ & $\%$ cumulatief \\
\hline 1 & 447 & 37,0 & 37,0 \\
$2-3$ & 83 & 6,9 & 43,9 \\
$4-7$ & 153 & 12,7 & 56,6 \\
$8-21$ & 315 & 26,0 & 82,6 \\
$22-34$ & 155 & 12,8 & 95,4 \\
$35-62$ & 56 & 4,6 & 100,0 \\
& 1209 & 100,0 & \\
\hline
\end{tabular}

Hoewel de talrijke groep eenmalig benoemden automatisch meebrengt dat een even groot aantal een totale carrièreduur van slechts één jaar had, is de spreiding bij de overigen zeer groot. De helft van de personen maakte een carrière van langer dan 5 jaren, voor 25\% duurde ze langer dan 16 jaren. Gemiddeld duurde een politieke loopbaan 10,37 jaren, de middelste 5,6 jaren. Trekt men van deze totale loopbaanduur de ambtsjaren af, dan blijkt hoeveel de wachttijden bedroegen: gemiddeld 2,56 jaren per carrière (mediaan : 2, standaarddeviatie : 2,14). Dit alles wijst er dus op dat normalerwijze de discontinuiteit in de ambtstoewijzing gehandhaafd bleef.

De doorstroming verschilde heel sterk volgens de functie. Daaruit blijkt dat er een duidelijke hiërarchie naar de plaats in de schepenbank bestond: in de hogere rangen overheersen de personen die vele ambten bekleedden, in de lagere daarentegen zijn de snelle doorstromers in de meerderheid. Opvallend is bovendien het onderscheid in dezen tussen de eerste schepenbank (van de Keure) en de tweede (van Gedele) : bij gelijke rang is het mutatieritme in de tweede groter en zijn dus de loopbanen korter dan in de eerste. Tabel 3 geeft enkele voorbeelden van de frequentie per functie van de personen die een bepaald antal ambten hebben bekleed. 
Tabel 3: Ambtsfrequentie per loopbaan en functiekategorie

\begin{tabular}{crrrrrr}
\hline $\begin{array}{c}\text { Loopbaan } \\
\text { met } x \text { ambten }\end{array}$ & \multicolumn{5}{c}{ Functiekategorieën } \\
& $2 \mathrm{e}$ & 6e & $12 \mathrm{e}$ & $2 \mathrm{e}$ & $6 \mathrm{e}$ & $12 \mathrm{e}$ \\
\hline 1 & 1 & 9 & 28 & 2 & 34 & 42 \\
2 & 6 & 12 & 22 & 13 & 14 & 20 \\
$3-5$ & 22 & 37 & 36 & 24 & 31 & 33 \\
$6-9$ & 38 & 27 & 18 & 41 & 20 & 3 \\
$10-15$ & 28 & 17 & 10 & 20 & 5 & - \\
\hline & 95 & 102 & 114 & 100 & 104 & 98 \\
\hline
\end{tabular}

Dat nog in 28 loopbanen met een hoger aantal ambten dan 5 een aanstelling als $12 \mathrm{e}$ schepen van de Keure voorkomt, is slechts schijnbaar in tegenstelling met het eerder genoemde verband. Vanuit die rang bestond immers een niet te verwaarlozen stijgingskans (zie verder tabel 7), cn die bestond in veel geringere mate vanuit de functic van $12 \mathrm{e}$ schepen van Gedele. Een andere manier om de doorstroming naar functiekategorie te belichten, bestaat erin het percentage te berekenen van hen die maar één keer werden aangesteld, gerelateerd aan alle bekleders van die functie.

Het mutatieritme blijkt een heel duidelijke indicator te zijn van de hiërarchie van en in de schepenbanken; de laagste helft van Gedele stroomt sneller door dan de staart van de Keure; daarbij zijn de twee laagste plaatsen van beide banken ieder naar verhouding afgetekend doorstroomplaatsen. De schepenbank van Gedcle kent als geheel een aanzienlijk hoger aantal eenmalige deelnemers. De zesde plaatsen, als laagste in rang gereserveerd voor de poorterij, markeren cen sprong, vooral bij Gedele; dit wijst op hun rol als intredeniveau voor deze klasse (zie tabel 4).

Het carrièreverloop kan in de ecrste plaats, en ook het gemakkelijkst worden geobserveerd aan het niveau van de intredefunctie. $77 \%$ van alle politici startten hun carrière in de lagere rangen, en $30 \% \mathrm{zelfs}$ in een van de vier laagste (de laatste schepenen van de $2 e$ bank). De vrij zeldzame gevallen van ,top-starters" laten zich verklaren hetzij door een rol in het ambachtswezen van waaruit de opstap naar de twee posities van overdeken gemaakt werd (23 gevallen), of door steun uit de gegoede burgerij die steeds beslag legde op beide voorzitterszetels. Vooral aan het hoofd van de tweede schepenbank verschenen nogal wat nieuwkomers (15 gevallen tegen 7 in de eerste bank). Het opklimmen van de ladder van de schepenambten gold niettemin wel als het normale carrièreverloop. (Zie tabel 5) 
Tabel 4: Percentage van de eenmalige ambtsbekleders per rang (de absolute aantallen schommelen rond $N=100$, behalve voor de voorschepenen).

Afkortingen $: O D=$ Overdeken van de Neringen $-D W=$ Overdeken van de Weverij - VK $=$ Voorschepen van de Keure $-\mathrm{VG}=$ Voorschepen van Gedele $-\mathrm{K} 3=$ derde schepen van de Keure - $G 6$ = zesde schepen van Gedele - OvS = overige schepenzetels.

\begin{tabular}{|c|c|c|c|c|c|}
\hline VK & 5,1 & $N=59$ & $V G$ & 6,4 & $N=78$ \\
\hline $\mathrm{K} 1$ & 2,2 & & G1 & 2,0 & \\
\hline 2 & 1,1 & & & 8,2 & \\
\hline 3 & 5,6 & & & 11,4 & \\
\hline 4 & 5,3 & & & 15,3 & \\
\hline 5 & 4,5 & & & 15,3 & \\
\hline 6 & 8,8 & & & 32,7 & \\
\hline 7 & 9,7 & & & 24,8 & \\
\hline 8 & 13,8 & & & 24,5 & \\
\hline 9 & 19,3 & & & 26,4 & \\
\hline 10 & 11,3 & & & 29,4 & \\
\hline 11 & 24,1 & & & 41,4 & \\
\hline 12 & 24,6 & & & 42,9 & \\
\hline
\end{tabular}

Tabel 5: Rang van de intredefunctie

\begin{tabular}{ccrrr}
\hline functierang & $\begin{array}{c}\text { aantal } \\
\text { personen }\end{array}$ & $\%$ & $\begin{array}{c}\text { gemiddeld aantal personen } \\
\text { per functierang }\end{array}$ \\
\hline 6 top & (a) & 60 & 5,3 & 10,0 \\
8 midden & (b) & 196 & 17,5 & 24,5 \\
10 lage & (c) & 531 & 47,3 & 53,1 \\
4 laagste & (d) & 335 & 29,9 & 83,8 \\
\hline 28 & & 1122 & 100,0 & 40,4 \\
\hline
\end{tabular}

(a) 2 overdekens, 2 voorschepenen (Keure en Gedele), 2 eerste schepenen (idem).

(b) 2e tot en met $5 e$ schepen van de Keure en van Gedele.

(c) 6e tot en met 12e schepen van Keure en 6e tot en met de 8e schepen van Gedele.

(d) $9 e$ tot en met 12e schepen van Gedele. 
Uit de laatste kolom blijkt dat de normale intrede in de politieke loopbaan onderaan de scherp gehiërarchiseerde schepenbanken plaatsvond, en dat in het bijzonder bijna $30 \%$ van alle ambtsdragers begonnen op een van de vier laagste plaatsen van de bank van de Gedele. Deze blijkt als inferieur te zijn beschouwd ten opzichte van de Keure: aanzienlijk meer carrières namen immers een aanvang bij Gedele, en in het bijzonder in de lagere rangen daar (tabel 6). De starters bij de Keure zijn in nog sterkere mate te vinden in de lagere rangen. Zoals reeds geconstateerd op grond van het mutatieritme, blijkt ook hier een dubbele hiërarchie in de Gentse schepenbanken te hebben bestaan: Keure genoot voorrang boven Gedele, en vervolgens was er de rangorde binnen elke bank. Op een gelijke functierang zijn er aanzienlijk meer politieke debuten in de bank van Gedele dan in die van de Keure : zo b.v. nog op de 4 e en se plaatsen, waarvoor de aantallen starters toevallig telkens gelijk zijn nl. 18 per functie bij de Keure tegenover 40 bij Gedele. Het afnemend aantal debuten naarmate de rang hoger is wijst er op dat er een patroon bestond volgens hetwelk meer ervaringsjaren werden verwacht van de bekleders van hogere schepenfuncties.

Tabel 6: Intreden per schepenbank en rang

\begin{tabular}{clll}
\hline & Keure & Gedele & Totaal \\
aantal & 397 & 702 & 1099 \\
waarvan in de & $289=73 \%$ & $463=66 \%$ & \\
8 laagste rangen & 51 & 83 & \\
\hline $9 \mathrm{e}$ & 45 & 82 & \\
$10 \mathrm{e}$ & 68 & 84 & \\
$11 \mathrm{e}$ & 72 & 86 &
\end{tabular}

Om dit patroon te achterhalen zijn tellingen uitgevoerd waarbij vanuit bepaalde startfuncties is nagegaan welke functies als $2 \mathrm{e}$, $3 \mathrm{e}$ en $4 \mathrm{e}$ functies werden uitgeoefend (tabel 7).

Tabel 7: Carrièreverloop van schepenen vanuit de 6 laagste rangen

\begin{tabular}{lcc|rccccccc} 
& Totaal & $\begin{array}{c}\text { \% t.o.v. } \\
\text { startgrocp }\end{array}$ & \multicolumn{2}{|c|}{ Le functie } & & & & & \\
& Laag $\%$ & Midden \% & Top \% & Kiezer \% \\
\hline Keure & 177 & 44,6 & 84 & 47,5 & 44 & 24,9 & 16 & 9,0 & 33 & 18,6 \\
Gedele & 265 & 37,7 & 165 & 62,3 & 67 & 25,3 & 13 & 4,9 & 20 & 7,5
\end{tabular}




\begin{tabular}{lcc|cccc} 
& Totaal & $\begin{array}{c}\text { \% t.o.v. } \\
\text { 2e functie }\end{array}$ & Laag & Midden & Top & Kiezer \\
\hline Keure & 43 & 24,3 & 21 & 12 & 5 & 5 \\
Gedele & 5 & 1,9 & 3 & 2 & - & -
\end{tabular}

\begin{tabular}{lcc|cccc} 
& Total & $\begin{array}{c}\text { \% functie } \\
\text { 3e functie }\end{array}$ & Laag & Midden & Top & Kiezer \\
\hline $\begin{array}{l}\text { Keure } \\
\text { Gedele }\end{array}$ & 22 & 51,2 & 11 & 4 & 2 & 5 \\
& - & - & - & - & -
\end{tabular}

Het carrièreverloop versterkt de reeds op grond van de startfuncties gedane vaststellingen: schepenen van de Keure hebben een beduidend hogere kans op herbenoemingen dan hun collega's van Gedele; van deze laatsten blijven er met een tweede functie aanzienlijk meer hangen in de lage rangen. Het volstaat niet om de mobiliteit vanuit de laagste rangen te beschouwen omdat daar het dubbele effect optreedt van het snelle verlaten van de politieke loopbaan en de opwaartse beweging. Daarom wordt vervolgens gezocht naar de vervolgfuncties vanuit het middenniveau.

Tabel 8: Carrièreverloop vanuit 3 middenrangen

\begin{tabular}{|c|c|c|c|c|c|c|c|c|c|c|c|c|}
\hline & \multirow[b]{2}{*}{$\begin{array}{l}\text { Totaal } \\
\text { starters }\end{array}$} & \multicolumn{2}{|c|}{$2 \mathrm{e}$ functie } & \multirow[b]{2}{*}{$\mathrm{L}$} & \multirow[b]{2}{*}{$\mathrm{M}$} & \multirow[b]{2}{*}{$\mathrm{T}$} & \multirow[b]{2}{*}{$\mathrm{K}$} & \multicolumn{2}{|c|}{$3 \mathrm{e}$ functio } & \multirow[b]{2}{*}{ M } & \multirow[b]{2}{*}{$\mathrm{T}$} & \\
\hline & & Tot. & $\%$ & & & & & Tot. & $\mathrm{L}$ & & & K \\
\hline Keure & 73 & 53 & 72,6 & 12 & 24 & 3 & 14 & 9 & - & 6 & - & 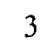 \\
\hline Gedele & 157 & 89 & 56,7 & 35 & 32 & 11 & 11 & 11 & 4 & 4 & 1 & 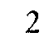 \\
\hline
\end{tabular}

De eerdere vaststellingen met betrekking tot de verschillende carrièrekansen in de twee banken vinden ook bevestiging voor middenrangen ( 4 e tot en met 6e plaatsen): aanzienlijk meer starters bij Gedele, duidelijk lagere kans op herbenoeming en een veel groter aandeel blijft hangen in de lagete- en middenrangen. Eén contrast nochtans : meer schepenen van Gedele stoten vanuit middenrangen door naar topposities. Daarbij is het echter opmerkelijk dat geen enkel van die twaalf gevallen betrekking 
heeft op een benoeming tot voorschepen of eerste schepen van de Keure. Tot die hoogten drong men kennelijk pas door na andere antichambres.

De doorstroming van lagere naar hogere functies verliep in de regel stapsgewijs : van een lage rang bij Gedele naar een lage bij de Keure of een middenpositie bij Gedele; van daaruit op naar een middenfunctie bij de Keure ; dan kwamen stappen naar de hoogste regionen in het bereik.

De strakke hiërarchie tussen en binnen de schepenbanken laat zich ook aflezen uit de telling van de percentages ambtsdragers die vanuit een bepaalde lage rang een top- of een middenniveau bereikten. De kansen om hogerop te komen stegen naarmate men al hoger in de hiërarchie stond - en dus in de regel ook al langer tot het politiek bedrijf behoorde. De afgetekend geringere promotiekansen vanuit alle rangen van de bank van Gedele tegenover de corresponderende posities in Keure neemt echter niet weg dat gemiddeld toch nog $14 \%$ van allen die ooit één van de zes laagste plaatsen bekleedden bij Gedele, zijn kunnen opklimmen tot topposities. Vanuit de zes laagste plaatsen van de Keure bereikte 1/4 een toppositie. De opwaartse mobiliteit was, ondanks de hoge uittredingsquotes, een realiteit (tabel 9).

De zesde en de derde schepenzetels van beide banken vertonen een sprongsgewijze hogere kans op topfuncties dan de $7 \mathrm{e}$, respectievelijk $4 \mathrm{e}$. Voor de beide zesde plaatsen gemiddeld bedraagt die kans $33 \%$, tegenover $19 \%$ voor de 12 lagere plaatsen. Dit laat zich verklaren door het feit dat zij, zoals de functies van voorschepen, voorbehouden waren aan de poorterij. Volgens de letter van de wet konden poorters dus alleen die zes functies bekleden. Uit ons onderzoek blijkt dat in de praktijk de mutaties inderdaad sterk binnen die kring verliepen maar dat er toch ook een niet te verwaarlozen minderheid bestond van overstappen naar sche-

Tabel 9: Hoogst bereikte niveau van allen die een bepaalde functie hebben bekleed (in \%).

\begin{tabular}{|c|c|c|c|c|c|c|}
\hline \multirow{2}{*}{$\begin{array}{l}\text { Uitgangs- } \\
\text { positie }\end{array}$} & \multicolumn{2}{|c|}{ Keure } & \multirow[b]{2}{*}{ Laag } & \multicolumn{3}{|c|}{ Gedcle } \\
\hline & Top & Midden & & Top & Midden & Laag \\
\hline 12 & 21,8 & 22,1 & 56,1 & 13,3 & 14,3 & 72,4 \\
\hline 11 & 18,5 & 26,9 & 54,6 & 7,1 & 16,2 & 76,8 \\
\hline 10 & 27,4 & 25,5 & 47,2 & 15,6 & 22,9 & 61,5 \\
\hline 9 & 24,8 & 23,9 & 51,4 & 19,1 & 25,5 & 55,5 \\
\hline 8 & 29,3 & 33,6 & 37,1 & 17,9 & 24,5 & 57,5 \\
\hline 7 & 25,2 & 31,1 & 43,7 & 11,5 & 24,8 & 63,7 \\
\hline 6 & 46,1 & 27,5 & 26,5 & 20,2 & 26,9 & 52,9 \\
\hline 5 & 43,6 & 56,4 & - & 21,6 & 78,4 & - \\
\hline 4 & 46,9 & 53,1 & - & 24,3 & 75,7 & - \\
\hline 3 & 60,7 & 39,3 & - & 37,5 & 62,5 & - \\
\hline 2 & 78,9 & 21,1 & - & 48,2 & 51,8 & - \\
\hline
\end{tabular}


penzetels die in theorie voorbehouden waren aan ambachtsgilden. Dit aandeel varieerde tussen een minimum van $18,5 \%$ van de herbezettingen vanuit de zesde zetel van Gedele tot een maximum van 29,3\% vanuit de zesde zetel van de Keure. Vanuit de vier zetels van de derde en zesde rang samen vond in $24,6 \%$ van de gevallen van herbezetting van een schepenzetel een benoeming plats op een post die voor een ambachtslid was voorbehouden. Dit impliceert dat in de praktijk de poorters een aanzienlijk grotere vertegenwoordiging in de politieke macht wisten te verwerven dan hun wettelijk was toegemeten. Ook het feit dat een aantal (38) van de overdekens - die toch geacht werden de ambachtslieden te vertegenwoordigen - tot de poorterij behoorden, wijst op een vervaging van die klassentegenstelling in het voordeel van de poorters (tabel 10).

Tabel 10: Carrièreverloop van schepenen uit de poorterij

Aantal ambtstermijnen naar rang en uitgangspositie

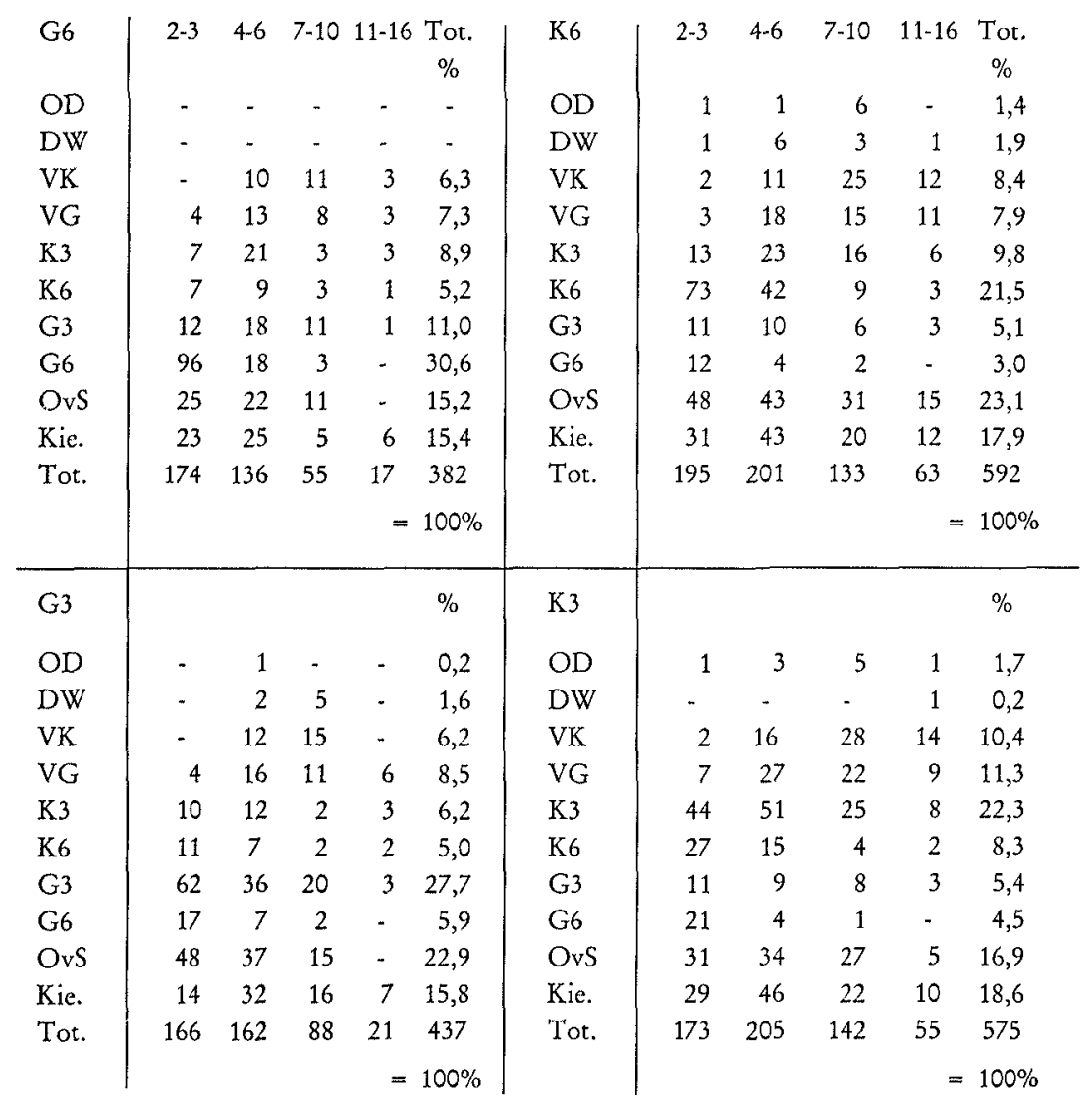

Afkortingen: zie tabel 4 ; Kie. = Kiesman 
Het carrièreverloop van de schepenen uit de poorterij, zoals dat af te leiden valt uit tabel 10 , herbevestigt de rangverschillen binnen en tussen de banken: de Keure levert aanzienlijk meer voorschepenen (van beide banken) dan Gedele : 222 tegen 116. De tijd speelt duidelijk een rol : men klimt op naar topfuncties, de schepenen van Gedele veelal eerst binnen hun eigen bank en pas daarna in die van Keure. Overstappen tussen beide banken zijn frequent, maar toch vinden veruit de meeste herbezettingen plaats binnen dezelfde rang en dat drie tot vier keer. Doorstoten naar de topfuncties van voorschepen deed men zelfs vanuit de reeds hoge derde zetel van de Keure pas vanaf zijn vierde ambtstermijn, en dan nog eerder naar die van Gedele en pas vanaf de zevende keer naar de echt allereerste plaats : voorschepen van de Keure.

Een aanstelling tot kiesman volgde in 15 tot $19 \%$ van alle herbenoemingen, met slechts een geringe afwijking naar rang en anciënniteit.

De constatering dat leden van de poorterij vanuit de derde en zesde zetels in $24,6 \%$ van de herbenoemingen tot schepen beslag wisten te leggen op door de ambachten te begeven zetels, nodigt uit tot het stellen van de vraag of het omgekeerde evenzeer het geval was. M.a.w. werden schepenen die een ,ambachtszetel" hadden bezet daarna nog benoemd op een ",poorterszetel"? Dit blijkt inderdaad ook wel het geval te zijn geweest, maar in veel geringere mate, $\mathrm{nl}$. in 36 van de 540 herbezettingen $(6,7 \%)$. De derde zetel van de Keure kwam daarbij opvallend minder in aanmerking ( 3 keer) dan de overige. In het algemeen blijkt dus de wettelijke zetelverdeling veel strikter te zijn geobserveerd ten aanzien van ambachtslieden dan ten aanzien van poorters, en wel afgetekend vanaf de vrede van Gavere van 1453 . Dit wijst er op dat de versterkte greep van de hertogelijke kommissarissen bij de wetsvernieuwing de positie van de poorterij bevoordeelde ten nadele van de ambachtslieden.

Het carrièrepatroon tenslotte van hen die de topfuncties bereikt hadden was eenvoudig: men bleef, zij het met de obligate (wettelijk voorziene) onderbrekingen. Het duurde normaal een aantal jaren en ambtstermijnen alvorens men het tot eerste schepen en voorschepen bracht, maar dan herhaalden de benoemingen zich ook vlot op hetzelfde niveau. Vanuit de functie van voorschepen vond herbenoeming vrijwel steeds in dezelfde rang plaats, met een markant overwicht naar voorschepen van de Keure: je moest al voorschepen geweest zijn om het zover te schoppen. Wanneer het om een $5 \mathrm{e}, 6 \mathrm{e}, 7 \mathrm{e}, 8 \mathrm{e}$ of $9 \mathrm{e}$ aanstelling ging, vormde alleen nog de rol van kiesman een alternatief; bij $2 \mathrm{e}$, $3 \mathrm{e}$ of $4 \mathrm{e}$ aanstellingen kon nog wel eens een uitwijking plaats vinden naar een andere hoge schepenplaats.

De overdekens van de Kleine Neringen komen ook regelmatig voor op schepenzetels, inclusief die van de poorterij, en als kiesmannen, dit laatste mogelijk in combinatie. Zelfs de plaatsen van voorschepen werden soms bekleed door gewezen overdekens, zij het dan via het tussenstadium van enkele schepenambten. De overdekens van de weverij, die een meer uitgesproken proletarische achterban hadden, zijn evenzeer terug te vinden op diverse schepenzetels. Onder hen heeft echter slechts één het gebracht tot voorschepen van Gedele, en dan nog pas als zijn twaalfde ambt. 
Tot nog toe is het carrièreverloop alleen beschouwd als een opeenvolging van ambtstermijnen. Wettelijk was echter een discontinuiteit voorzien die geen wederopname toeliet in dezelfde schepenbank tijdens een onmiddellijk volgend jaar. Dit betekende dus dat een loopbaan waarin twee ambten werden bekleed, tenminste drie jaren duurde, in zoverre de wet werd nageleefd. Nu blijkt inderdaad de feitelijke carrièreduur aan zienlijk meer te belopen dan de som van de ambtsjaren (tabel 11).

Tabel 11: Gemiddelde carrièreduur en verhouding tot de effectieve ambtstermijnen, naar enkele type-rangen.

\begin{tabular}{|c|c|c|c|c|c|}
\hline & jaren & $\begin{array}{l}\text { verhouding } \\
\text { ambtstermijn- } \\
\text { carrièreduur } \\
\text { (mediaan) }\end{array}$ & & jaren & $\begin{array}{l}\text { verhouding } \\
\text { ambtstermijn } \\
\text { carrièreduur } \\
\text { (mediaan) }\end{array}$ \\
\hline VK & 24 & 0,250 & VG & 26 & 0,231 \\
\hline K 1 & 23 & 0,333 & G 1 & 23 & 0,276 \\
\hline K 2 & 25 & 0,294 & $G 2$ & 22 & 0,282 \\
\hline K 3 & 22 & 0,267 & G 3 & 24 & 0,273 \\
\hline K 4 & 21 & 0,273 & G 4 & 16 & 0,308 \\
\hline K 6 & 20 & 0,286 & G 6 & 13 & 0,353 \\
\hline K 9 & 13 & 0,333 & G 9 & 14 & 0,333 \\
\hline $\mathrm{K} 12$ & 13 & 0,379 & G12 & 8 & 0,500 \\
\hline
\end{tabular}

Een verhoudingscijfer 0,333 geeft aan dat een persoon in 1 jaar op 3 effectief een ambt heeft bekleed, met 0,250 is dat 1 op 4 . In de hogere rangen blijkt de normale spreiding van ambten over de carrière te liggen tussen die twee cijfers. Dit houdt in dat op dit punt de wettelijk voorziene discontinuiteit van politieke ambten globaal ruimschoots werd gerespecteerd. Daarbij flatteren de verhoudingscijfers nog omdat de functie van kiesman, die onverenigbaar was met de uitoefening van een schepenambt, als volwaardig is meegerekend, hoewel het slechts een ééndaagse activiteit betrof. Dit verklaart ook waarom in de kortere loopbanen aan de basis van de hiërarchie de verhouding opliep tot meer dan 1 functie op drie jaar.

In het algemeen correleert een hoge ambts-/carrièreduur verhouding sterk met een hoog aantal functies: $\mathrm{R}=0,74$. Bovendien correleert de carrièreduur met een hoog bereikt functieniveau : gamma $=0,623$. Eenvoudig geformuleerd : wie een lange politieke loopbaan makte, bekleedde daarin vele ambten en ook hoge.

$\mathrm{Na}$ de analyse van carrièrepatronen, bieden onze gegevens ook de mogelijkheid om de mutatieritmen in het tijdsverloop te bekijken. Zijn er in bepaalde perioden aanzienlijke fluctuaties te bespeuren in de intrede en uittrede van politici? Tabel 12 presenteert die tellingen eerst op een sta- 
Tabel 12: Doorstroming van politici per tijdvak. Vittredingen per decennium.

\begin{tabular}{ccccc}
\hline & $N$ & $\%$ & $\%$ cum. \\
$1400-1409:$ & 72 & 5,9 & 5,9 \\
$1410-1419:$ & 85 & 7,0 & 12,9 \\
$1420-1429:$ & 76 & 6,3 & 19,2 \\
$1430-1439:$ & 98 & 8,1 & 27,3 \\
$1440-1449:$ & 113 & 9,3 & 36,6 \\
$1450-1459:$ & 118 & 9,7 & 46,3 \\
$1460-1469:$ & 84 & 6,9 & 53,3 \\
$1470-1479:$ & 140 & 11,5 & 64,8 \\
$1480-1489:$ & 145 & 12,0 & 76,8 \\
$1490-1499:$ & 125 & 10,3 & 87,1 \\
$1500-1509:$ & 95 & 7,8 & $94,9(\mathrm{a})$ \\
\hline $1510-1519:$ & 24 & 2,0 & 96,9 \\
$1520-1529:$ & 26 & 2,1 & 99,0 \\
$1530-1539:$ & 11 & 0,9 & 99,9 (b) \\
(a) De gegevens zijn volledig tot 1506. & \\
(b) Na 1540 eindigt nog 1 loopbaan. & \\
\hline
\end{tabular}

Periodisering volgens politieke conflicten (jaargemiddelden)

\begin{tabular}{ccccc}
\hline \multicolumn{4}{c}{ Nieuwkomers, waarvan eenmalig } & Uittredens \\
$1400-1435$ & 7,8 & 2,5 & $1400-1435$ & 8 \\
$1437-1443$ & 14,3 & 4,7 & & \\
$1449-1456$ & 14,6 & 7,1 & $1449-1450$ & 30 \\
& & & $1452-1453$ & 23 \\
$1457-1476$ & 9,4 & 4,0 & $1457-1476$ & 10,25 \\
$1477-1491$ & 17,3 & 7,6 & 1485 & 28 \\
& & & 1490 & 24 \\
$1492-1505$ & 9,3 & 4,0 & $1495-1506$ & 9,8 \\
\hline
\end{tabular}

tistisch-neutrale wijze volgens decennia, en vervolgens toegespitst op de perioden van politieke strijd 1449-53 en 1477-92.

Gemeten per decennium, blijken de jaren 1440-1459 en $1470-1499$ een opvallend hoger aantal uittredens te vertonen dan alle andere perioden ; daarbij scoorden de jaren '70 en ' 80 nog aanzienlijk hoger dan de andere. Het gaat hier om het eerder aangetoonde verschijnsel van een ver- 
snelde personeelswisseling tijdens de politieke crisissen ${ }^{10}$. Indien we juist die perioden afzonderen, blijkt die versnelling tot bijna een verdubbeling van het mutatieritme te leiden met een iets minder dan evenredige stijging van het aandeel van de eenmalig optredende figuren. Het normale wisselingsproces, dat zich gedurende cen zeventigtal jaren in de onderzochte periode 1400-1506 heeft voorgedaan, hield in dat jaarlijks 8 tot 9 nieuwelingen verschenen op het politieke toneel. Bij een totaal van 32 tot 36 te begeven functies (het aantal kiesmannen varieerde) is dit ieder jaar een kwart nieuwe gezichten, wat zeer veel is. Een honderdtal onder hen traden alleen op als kiesman, maar ook wanneer die buiten beschouwing blijven, blijft het Gentse stadsbestuur in de 15 de eeuw gekenmerkt door een zeer hoge doorstroming. Na 1435 lag het aantal van de eenmalige ambtsbekleders nog wat hoger (4 per jaar) dan daarvoor (2,5 per jaar). Een enigszins onverwacht verschijnsel laat zich nog uit deze gegevens aflezen. Van 1437 tot 1443 onderging het Gentse stadsbestuur jaarlijks een vernieuwing van de helft van zijn leden, zonder dat de stad in opstand was. Wel waren er in de voorbije jaren relletjes geweest, en was de stad Brugge openlijk in opstand. Mogelijk heeft ook de pestepidemie van 1437-38 enige invloed uitgeoefend op het hoge vervangingscijfer, maar die sleepte dan toch niet aan tot 1443 . Opvallend is nog dat van de gemiddeld 14.3 nieuwkomers per jaar er 9,6 in het bestuur bleven, aanzienlijk meer dus dan normaal, en ook veel meer dan tijdens de opstand van 1449-53. De verklaring kan zijn dat de hertog, in het kader van de centralisatiepolitiek die hij juist vanaf ca. 1430-35 krachtig op gang had gebracht, ook in het Gentse stadsbestuur een nieuwe groep aan de macht heeft gebracht, in de hoop daarmee de opstandigheid van de stad te fnuiken. Zijn misrekening blijkt uit de latere gegevens.

$\mathrm{Bij}$ de uittredecijfers valt nog op te merken dat die in de perioden na de opstanden hoger zijn dan die van de intredens, wat op politieke zuivering wijst. Confrontatie met de uittredecijfers per decennium leert dat men na 1460 opnieuw in een rustig vaarwater verkeerde, meer dan na 1500 .

De laatste te behandelen invalshoek is die van de familiebanden. Zonder uitgebreid genealogisch onderzoek valt in een zo grote stad als Gent niet zondermeer op grond van de naam te besluiten tot het bestaan van een verwantschap. Er zijn echter ook al op grond van aanduidingen van beroep, titel, woonplaats of afstamming toch wel zekere banden vast te stellen, die bij uitstek opvallen bij enkele vanouds bekende patriciërsgeslachten. Zo blijkt de intergenerationele continuïteit in het Gentse stadsbestuur in sommige families zoals Borluut, Utenhove, Sersanders of Sersymoens, zich uit te strekken van de 13 de tot de 16de eeuw. De familie Vaennewijc trad pas vanaf de 14 de eeuw op het politieke voorplan, maar

(10) W.P. BLOCKMANS, Mutaties van het politiek personeel in de steden Gent en Brugge tijdens een periode van regimewisselingen: het laatste kwart van de 15 de eeuw, in: Bronnen voor de Geschiedenis van de Instellingen in België (Brussel 1976), 92-103. 
zij bleef er dan ook gedurende eeuwen ${ }^{11}$. Van de 42 poortersfamilies die Rogghé in de tweede helft van de 14 de eeuw heeft opgespoord, waren er tijdens de 15 de eeuw nog 27 aktief als schepenen. Zij telden gemiddeld 4,6 leden in het stadsbestuur, tegenover 4,1 voor de gehele populatie. Van deze 124 telgen uit de oude poorterij bereikten $41 \%$ topposities; vanuit de zesde schepenzetels, de laagste die voorbehouden waren aan de poorterij, klom $33 \%$ op naar een toppositie; de leden van oude families makkten het dus duidelijk beter. Ondanks het eclipseren van één derde van de families tijdens de 15 de eeuw (sommige zoals de Beere, Rijvisch en van Lede zouden overigens in de 16de weer op het voorplan treden) vormden de oude poortersfamilies dus een machtsbestendigende factor in het Gentse stadsbestuur. Eenvoudig telwerk op grond van homonymen, getoetst aan bovengenoemde kriteria, levert op dat de doorsnee Gentse politicus behoorde tot een verwantschap met gemiddeld 4,1 leden in het stadsbestuur. De mediaan bedraagt 2,6 , wat er op wijst dat er nogal wat heel grote families opereerden. De verdeling blijkt uit tabel 13 .

Tabel 13: Omvang van de politieke families

\begin{tabular}{ccccc}
\hline Ledental & N families & N personen & $\%$ & $\%$ cumul \\
1 & 377 & 377 & 31,2 & 31,2 \\
2 & 103 & 206 & 17,0 & 48,2 \\
3 & 53 & 159 & 13,1 & 61,3 \\
$4-5$ & 33 & 145 & 12,0 & 73,3 \\
$6-9$ & 21 & 152 & 12,6 & 86,0 \\
$10-14$ & 15 & $\underline{170}$ & 14,0 & 100,0 \\
& $\mathbf{1 0 2}$ & 1209 & 100,0 & \\
\hline
\end{tabular}

Er blijken heel duidelijke correlaties te bestaan tussen het behoren tot een grote familie enerzijds, en het doorlopen van een lange loopbaan met het bereiken van hoge functies anderzijds (tabel 14).

Hoewel het verband tussen politiek succes en de verwantschap aan vele andere politici opvallend genoemd kan worden, is een genuanceerde benadering geboden. Bijna de helft van de leden van families met 9 leden in het circuit bleven immers hangen in de lagere ambten ; in het algemeen zijn de lage en middenfuncties toch altijd goed voor tweederden van de ambten in families met 5 en meer leden (tabel 15).

(11) Thomas wordt in 1302 vermeld als lakenhandelaar: F. BLOCKMANS, Het Gentsche stadspatriciaat tot omstreeks 1302 (Antwerpen 1938) 268-269; ROGGHE, Samenstelling, 30 . 
Tabel 14: Familieomvang en ambtsfrequentie

\begin{tabular}{c|cccc} 
& \multicolumn{4}{|c}{ Aantal ambten per persoon (voorbeelden) } \\
Familie- & 1 & 5 & 9 & 12 \\
omvang & $36,6 \%$ & $6,9 \%$ & $2,3 \%$ & $1,3 \%$ \\
\hline 1 & $\mathrm{~N}=444$ & $\mathrm{~N}=84$ & $\mathrm{~N}=28$ & $\mathrm{~N}=16$ \\
\hline 2 & $39,6 \%$ & $22,6 \%$ & $10,7 \%$ & $18,8 \%$ \\
3 & 16,4 & 17,9 & 14,3 & 18,8 \\
$4-5$ & 10,8 & 17,9 & 21,4 & 6,2 \\
$6-9$ & 8,8 & 12,9 & 14,3 & 12,5 \\
$10-14$ & 13,8 & 13,2 & 10,7 & 6,2 \\
& 10,6 & 15,2 & 28,6 & 37,5 \\
\cline { 2 - 5 } & 100,0 & 100,0 & 100,0 & 100,0
\end{tabular}

Tabel 15: Hoogst bereikte functie en familieomvang

\begin{tabular}{c|ccc|rr}
$\begin{array}{c}\text { Familie- } \\
\text { omvang }\end{array}$ & Top & Midden & Laag & \multicolumn{2}{|c}{ Aantal personen } \\
\hline 1 & $16,4 \%$ & $31,0 \%$ & $52,6 \%$ & $100 \%$ & $\mathrm{~N}=377$ \\
5 & 31,7 & 36,7 & 31,7 & & 61 \\
9 & 28,9 & 22,2 & 48,9 & & 45 \\
12 & 33,3 & 41,7 & 25,0 & & 36 \\
14 & 42,9 & 57,1 & 0 & & 14
\end{tabular}

Een analyse van de 15 families die 10 en meer leden in het politiek apparaat telden, toont aan dat de rangopbouw nogal gevarieerd is. De absolute topfamilie van Gent, het oude patriciërsgeslacht Utenhove, had van 1398 tot 150314 telgen in het bestuur, onder wie 6 op topniveau, 4 op midden- en 4 op het lage niveau. Hoewel niet alle een gelijksoortige spreiding vertonen, hebben alle grote families naast enkele topfiguren ook een reeks lieden van tweede en derde garnituur in hun rangen. Hun aanwezigheid kan natuurlijk een strategisch belang gehad hebben, juist in combinatie met de rol van de machtige peetvaders. In de meeste families kan inderdaad een soort stamvader aangewezen worden die binnen de bestudeerde periode als eerste in zijn generatie topposities bekleedde, en jongere verwanten in zijn kielzog aantrok. Sommigen, zoals De Brunes en de Goetghebuers hebben pas tijdens de jaren '20 en ' 30 hun macht gevormd, terwijl de meesten juist tijdens de hele periode aktief waren (tabel 16). 
Tabel 16: De grote politieke families

\begin{tabular}{lcccccccc}
\hline & periode & $\begin{array}{c}\text { aantal } \\
\text { politici }\end{array}$ & \multicolumn{3}{c}{$\begin{array}{c}\text { functie- } \\
\text { niveau's }\end{array}$} & $\begin{array}{c}\text { stam- } \\
\text { vader }\end{array}$ & niveau & $\begin{array}{c}\text { aantal } \\
\text { functies }\end{array}$ \\
& & & $\mathrm{T}$ & $\mathrm{M}$ & $\mathrm{L}$ & & & \\
\hline Utenhove & $1398-1503$ & 14 & 6 & 4 & 4 & $1398-1431$ & $\mathrm{~T}$ & 12 \\
van der Haghe & $1409-1505$ & 13 & 2 & 1 & 10 & $1409-1412$ & $\mathrm{~T}$ & 2 \\
de Vos & $1408-1510$ & 13 & 2 & 2 & 9 & - & - & - \\
de Grave & $1416-1497$ & 12 & 5 & 1 & 6 & - & - & - \\
de Grutere & $1401-1526$ & 12 & 4 & 5 & 3 & $1401-1443$ & $\mathrm{~T}$ & 12 \\
van Loo & $1392-1514$ & 12 & 3 & 6 & 3 & $1392-1421$ & $\mathrm{M}$ & 2 \\
de Brune & $1421-1536$ & 11 & 4 & - & 7 & $1421-1450$ & $\mathrm{~T}$ & 12 \\
Damman & $1386-1508$ & 11 & 2 & 6 & 3 & $1386-1423$ & $\mathrm{~T}$ & 10 \\
van der Eeken & $1377-1512$ & 11 & 6 & 2 & 3 & $1377-1422$ & $\mathrm{~T}$ & 10 \\
de Moere & $1397-1511$ & 11 & 7 & 2 & 2 & $1397-1412$ & $\mathrm{~T}$ & 7 \\
Goetghebuer & $1430-1501$ & 10 & 5 & 3 & 2 & $1430-1464$ & $\mathrm{~T}$ & 12 \\
van Melle & $1429-1523$ & 10 & 1 & 4 & 5 & $1429-1446$ & $\mathrm{M}$ & 3 \\
Meyeraert & $1401-1516$ & 10 & 4 & 3 & 3 & $1401-1431$ & $\mathrm{~T}$ & 12 \\
Sersanders & $1400-1520$ & 10 & 5 & 1 & 4 & $1400-1428$ & $\mathrm{~T}$ & 9 \\
Vaernewijc & $1384-1518$ & 10 & 4 & 6 & - & $1384-1412$ & $\mathrm{M}$ & 8 \\
\hline
\end{tabular}

Beschouwt men de familieomvang in specifieke functies, dan treedt daaruit nog een ander aspect naar voren dan de al genoemde correlatie met het niveau. Familiebanden blijken een grotere rol te hebben gespeeld in de functies die voorbehouden waren aan de poorterij. Vanzelfsprekend geldt dit voor de voorschepenen, maar in het bijzonder ook voor de derde en zesde zetels. Omgekeerd wogen de familiebanden minder zwaar bij de overdekens dan bij de voorschepenen. Hieruit zou het besluit kunnen getrokken worden dat de gegoede burgerij meer dan de ambachtslieden haar machtspositie opbouwde langs verwantschapslijnen (tabel 17).

Tabel 17: Verwantschap bij poorters en ambachtsleden.

\begin{tabular}{c|rrrrrr|rrrr} 
& \multicolumn{7}{|c|}{ Poorters } & \multicolumn{4}{|c}{ Ambachtsleden } \\
$\begin{array}{c}\text { Familie- } \\
\text { omvang }\end{array}$ & VK & VG & K3 & K6 & G3 & G6 & OD & DW & K4 & G4 \\
\hline 1 & 5 & 10 & 24 & 22 & 13 & 25 & 12 & 13 & 27 & 34 \\
2 & 7 & 6 & 5 & 15 & 8 & 15 & 11 & 6 & 20 & 19 \\
$3-5$ & 19 & 28 & 24 & 28 & 26 & 22 & 11 & 19 & 38 & 30 \\
$6-14$ & 28 & 34 & 37 & 37 & 41 & 42 & 15 & 15 & 28 & 28 \\
\hline Tot. & 59 & 78 & 89 & 102 & 88 & 104 & 49 & 53 & 113 & 111
\end{tabular}


Twee personengroepen verdienen tot slot nog bijzondere aandacht: de edelen en de ambtenaren. Eerder constateerden we het kleine aantal edelen, nl. 28 in het hele bestand van 1209. Een nadere beschouwing van hun optreden dwingt echter ook hier tot belangrijke nuanceringen. Van deze 28 oefenden 21 topfuncties uit, de overigen aanzienlijke ambten in het middenkader. Het proletarische Gent zag kennelijk niet ongaarne adellijke praal aan het hoofd van het stadsbestuur.

Deze vaststelling geldt in het bijzonder in tijden van politieke crisis : juist dan wordt kennelijk vanuit de ambachtsgilden een beroep gedaan op edelen om de functie van voorschepen waar te nemen. Hoewel de aanwezigheid van edelen zich niet tot die moeilijke omstandigheden beperkt, is hun aanwezigheid in fases van acute weerstand tegen het vorstelijk gezag opmerkelijk. Maar ook tijdens restauratieperioden treden edelen op de voorgrond, en sommigen slagen er zelfs in om, zoals ridder Adriaan van Ravenschoot en jonkheer Louis van Massemen, de eerste rangsrol te spelen in het heetst van het verzet evenzeer als na de onderwerping. Het prestige van deze edelen werd blijkbaar door alle partijen aangegrepen om vertrouwen in te boezemen en ontzag af te dwingen binnen en buiten de stadsmuren. Uit dien hoofde konden zij ook bijdragen tot de pacificatie na een jarenlange opstand.

Tabel 18: Edelen op de bres

\begin{tabular}{lll}
\hline $\begin{array}{lll}\text { Restauratie } \\
\text { ridder Gillis Haghelin }\end{array}$ & & \\
mer Clais Triest & 1455 & VK \\
& 1447 & VK \\
heer Jan II van Vaernewijc & 1438 & VK \\
& 1455 & VG \\
& 1467 & VG \\
& 1469 & VK \\
heer Jan van Vaernewijc & 1455 & G4 \\
& 1467 & K1 \\
& 1475 & VG \\
& 1485 & VK \\
mer Jan van Loo & 1455 & G3 \\
& 1457 & K5 \\
& 1469 & G1 \\
ridder Gerard Triest & 1476 & VG \\
ridder Roeland van Wedergrate & 1468 & VK \\
& 1476 & VK
\end{tabular}




\begin{tabular}{|c|c|c|c|c|}
\hline \multicolumn{3}{|l|}{ Opstand } & \multicolumn{2}{|c|}{ Restauratie } \\
\hline \multirow[t]{2}{*}{ ridder Roeland de Baenst } & 1477 & VG & & \\
\hline & 1478 & VK & & \\
\hline \multirow{3}{*}{ ridder Joos van Ghistel } & 1477 & VK & & \\
\hline & 1480 & VK & & \\
\hline & & & 1486 & VK \\
\hline \multirow[t]{5}{*}{ ridder Adriaan van Ravenscoot } & 1477 & VK & & \\
\hline & 1479 & $\mathrm{VK}$ & & \\
\hline & & & 1487 & VK \\
\hline & & & 1492 & VK \\
\hline & & & 1496 & VK \\
\hline mer Martin van Ghend & 1477 & $\mathrm{~K} 2$ & & \\
\hline \multirow[t]{3}{*}{ ridder Adriaan Vilain } & 1479 & VG & & \\
\hline & 1481 & VK & & \\
\hline & 1487 & VK & & \\
\hline \multirow[t]{2}{*}{ mer Laureins van den Berghe } & & & 1486 & G2 \\
\hline & & & 1492 & G6 \\
\hline jonkheer Adriaan van Scoonhove & 1488 & $\mathrm{~K} 4$ & & \\
\hline jonkheer Jan van der Valleyen & 1489 & K3 & & \\
\hline \multirow[t]{4}{*}{ jonkheer Louis van Massemen } & 1489 & VK & & \\
\hline & & & 1492 & VG \\
\hline & & & 1494 & VK \\
\hline & & & 1498 & VK \\
\hline
\end{tabular}

Rogghé publiceerde een lijst van 182 bedienaars van de ambten van pensionaris en secretaris tijdens de 15 de eeuw en constateerde bij deze ambtenaren een "onbedwingbare rush" naar de ambten van schepen, tresorier en ambachtsdeken, en wees er ook op dat enkele tientallen vervolgens ambten in dienst van de vorst aanvaardden ${ }^{12}$. Inderdaad vervulden ruim één derde van de pensionarissen en secretarissen functies als schepen, kiesman en overdeken. Zou men ook de tresoriersambten in de beschouwing betrekken, evenals functies als provisor van gasthuizen en Tafels van de Heilige Geest, dan zou de verwevenheid van de Gentse bestuurselite ongetwijfeld nog veel frappanter aan het licht komen. Bovendien treft men in de lijst van ambtenaren ook talloze familieleden an van schepenen, in het bijzonder onder de poorters. De universitaire studies die althans voor het pensionarisambt een vereiste waren, werden immers overwegend volbracht door telgen uit gegoede families.

Het feit nu dat ambtenaren regelmatig ook politieke ambten bekleedden heeft een aantal consequenties. Het geringe aantal van meesters in ons bestand van politici - 19 op $1209,1,6 \%$ - is zeer laag in vergelijking met de ruim $40 \%$ in Leuven en Antwerpen, ook al situeert een over-

(12) ROGGHE, De Gentse klerken, 116-120 en de lijst op 133-138. 
wegend deel daarvan zich in de 16 de eeuw ${ }^{13}$. Nu blijken deze universitair geschoolde schepenen de pensionarissen te zijn die een overstap maakten naar de politiek. Als zodanig waren de Gentse schepenen dus niet gericht op een universitaire titel; waar die in zeldzame gevallen voorkwam, was hij afgeleid van cen eerder beklede ambtelijke functie. Aangezien pensionarissen frequent optraden als kiesman, beïnloedden zij mee de samenstelling van de schepencolleges; dit leidde blijkbaar tot ruilverhoudingen. Hoewel de uitdrukking „onbedwingbare rush" in dit verband overdreven klinkt, is er niettemin sprake van een sterke verwevenheid tussen ambtenaren en politici. Rogghés lijsten laten helaas niet toe vast te stellen in welke mate pensionarissen na een ambtstermijn als schepen konden terugkeren in hun oude functie. Indien dat het geval zou zijn, zouden deze heren slechts nu en dan van stoel wisselen zonder nadeel te ondervinden van de wettelijke en feitelijke discontinuïteit in de politieke functies. In hun dagelijkse werkzaamheden stonden de pensionarissen zeer dicht bij de schepenen, maar door hun vaste anstelling bouwden zij doorgaans een ruimere en vooral continuë ervaring op. Zo namen pensionarissen steeds deel aan gezantschappen naast enkele schepenen. Op die manier bouwden zij een jaargemiddelde aan delegaties op dat alleen geëvenaard werd door de voorschepenen; die oefenden hun functie evenwel niet continu uit, wat de ambtenaren een informatievoordeel opleverde. Overigens bevestigt de frequentie waarmee aan gezantschappen werd deelgenomen volstrekt de hiërarchie die is vastgesteld op grond van het doorstroomritme van schepenen: de zes topfunctionarissen vervulden samen $52 \%$ van alle delegaties, de schepenen van de Keure ruim dubbel zoveel als die van Gedele, en de zes lagere rangen van beide colleges leverden samen amper $11 \%$ van alle delegatielieden ${ }^{11}$. Zo blijkt de hiërarchie binnen de magistraat ook scherp in de wijze waarop die naar buiten trad; daarbij had een pensionaris evident veel meer invloed dan de ,backbenchers".

Bij wijze van besluit kan de vraag opgeworpen worden naar de feitelijke werking van de participatie van ambachtslieden in het stadsbestuur; te Gent werd hun constitutioneel een veel groter aandeel geboden dan in enige andere stad in de Nederlanden. Dit onderzoek heeft aangetoond dat het grote aantal schepenzetels voorbehouden aan ambachtslieden (20 op 26) niet leidde tot een evenredige machtsuitoefening. Leden van de poorterij behielden een relatief grote greep op het bestuur doordat zij

- per persoon meer aanstellingen verwierven en derhalve een langere verblijfsduur haalden,

(13) H. DE RIDDER-SYMOENS, De universitaire vorming van de Brabantse stadsmagistraat en stadsfunktionarissen - Leuven en Antwerpen, 1430-1580, in : Verslagboek viffde Colloquiam De Brabantse Stad, 1977, 58-65, 108-115.

(14) W.P. BLOCKMANS, De Volksvertegenwoordiging in Vlatanderen in de overgang van middeleenwen naar niewwe tijd (1384-1506) (Verhandelingen Kon. Academie voor Wetenschappen, Letteren en Schone Kunsten van België, 90, Brussel 1978), 570-579, 639-641. 
- meer kans maakten op topposities,

- meer familieleden telden in het stadsbestuur en de ambtenarij,

- na 1453 in belangrijke mate plaatsen bekleedden die theoretisch voorbehouden waren aan ambachtslieden, waaronder zelfs de invloedrijke positie van overdeken van de neringen,

- vooral als voorschepenen en pensionarissen een overwicht genoten in de externe vertegenwoordiging van de stad.

De snelle doorstroming van ambachtslieden bemoeilijkte effectieve machtsvorming zelfs zo sterk dat het leiderschap tijdens revolten nog aan edelen en poorters werd toevertrouwd. De discontinuiteit in de politieke machtsuitoefening die was ingevoerd om misbruiken te voorkomen zoals die tijdens het oude patriciësbewind, die discontinuiteit bleek ambachtslieden meer te hinderen inzake machtsvorming dan poorters. Deze laatsten konden het dankzij hun persoonlijk fortuin gemakkelijker af en toe een jaar zonder formeel salaris stellen; bovendien vielen hun talloze andere functies toe die het hun mogelijk maakten ondanks de discontinuïteit in het schepenambt een vrijwel continuë politieke loopbaan op te bouwen. Er zijn aanwijzingen dat de ambachtsbesturen en de ambachtsvertegenwoordiging in de stadsbesturen oligarchische en zelfs plutocratische tendenzen vertoonden, althans te Brugge en te Brussel waar dergelijk onderzoek is verricht ${ }^{15}$. Indien dit ook te Gent het geval zou zijn, zou zulks de betekenis van de talrijke ambachtszetels in de schepencolleges nog verder reduceren : wie er immers langer vertoefde dan de vele eenmalig benoemden, was al zo nauw verstrikt in de gevestigde orde dat hij geen authentiek vertegenwoordiger meer kon zijn van belangen van de duizenden ambachtslieden. Dit zou dan de vele uitbarstingen van volkswoede tegen de eigen bestuurders helpen verklaren.

(15) J.P. SOSSON, Les Travaux publics de la ville de Bruges, XIVe-XVe siècles (Pro Civitate 48, Brussel 1977) 193-201; J. MERTENS, De Brugse ambachtsbesturen (1363-1374 n.s.) : een oligatchie? in : Recht en Instellingen in de oude Nederlanden tijdens de Middeleeuwen en de Nieuwe Tijd. Liber Amicortum Jan Buntinx (Symbolae A 10, Leuven 1981) 185-198; daar ook verwijzing naar overige studies terzake van Sosson. Er is alvast één opvallend verschil tussen Brugge en Gent : terwijl schrijnwerker $G$. van der Houtmersch en metselaar J. van Oudenaerde rond 1400, jaar na jaar raad en/of schepen waren (SOSSON, 194, 196), treft men te Gent dergelijke continuïteiten niet aan. Na 1411 blijken ze trouwens ook te Brugge niet meer uit de beschikbare gegevens. 